\title{
Use of Pegvisomant in acromegaly. An Italian Society of Endocrinology guideline
}

\author{
A. Giustina • M. R. Ambrosio - P. Beck Peccoz • \\ F. Bogazzi - S. Cannavo' $\cdot$ L. De Marinis • \\ E. De Menis $\cdot$ S. Grottoli $\cdot$ R. Pivonello
}

Received: 30 April 2014 / Accepted: 4 June 2014/Published online: 23 September 2014

(C) The Author(s) 2014. This article is published with open access at Springerlink.com

Keywords Pegvisomant $\cdot$ Acromegaly $\cdot$ Somatostatin analogs · Growth hormone $\cdot$ IGF-1

\section{Introduction}

Acromegaly management is a significant challenge for endocrinologists. The Acromegaly Consensus Group developed several statements on the management of acromegaly and specifically on its medical treatment [1-3]. Acromegaly is a quite rare condition generally caused by a growth hormone $(\mathrm{GH})$-secreting pituitary adenoma [4]. Delayed diagnosis leads to prevalent presentation of the disease at the stage of macroadenoma (two-thirds of patients) and frequent persistence of active disease after surgery which remains in many patients the primary

\footnotetext{
A. Giustina $(\square)$

Struttura Ambulatoriale di Endocrinologia, A.O. Spedali Civili di Brescia, University of Brescia, Via Biseo 17, 25100 Brescia, Italy

e-mail: a.giustina@libero.it

M. R. Ambrosio

Department of Medical Science, University of Ferrara, Ferrara, Italy

P. Beck Peccoz

Endocrinology, Fondazione IRCCS Ca' Granda Policlinico,

University of Milano, Milan, Italy

F. Bogazzi

Section of Endocrinology, Department of Clinical and

Experimental Medicine, University of Pisa, Pisa, Italy

S. Cannavo'

Department of Clinical and Experimental Medicine, University

of Messina, Messina, Italy
}

treatment option [5]. However, active acromegaly is potentially a life threatening condition due its severe systemic complications [6, 7] Therefore, elevated GH and insulin-like growth factor (IGF)-1 levels need to be strictly controlled after failure of surgery with medical or radiation treatments [8]. Furthermore, criteria for disease control may not be fulfilled in a considerable proportion of patients undergoing medical treatment with somatostatin receptor ligands (SRLs) after unsuccessful surgery [9, 10]. Accordingly, some acromegaly patients require the administration of GH antagonist Pegvisomant [11]. Pegvisomant has been introduced in clinical practice more than a decade ago as a medical therapy of acromegaly. However, specific guidelines for Pegvisomant use in acromegaly are lacking. Therefore, the Italian Society of Endocrinology constituted a task force with the objective

\author{
L. De Marinis \\ UOS Patologia Ipofisaria, Policlinico Universitario A. Gemelli, \\ Rome, Italy \\ E. De Menis \\ Internal Medicine, Montebelluna Hospital, Montebelluna, Italy \\ S. Grottoli \\ Endocrinology, Diabetology and Metabolism, AO Città della \\ Salute e della Scienza di Torino, University of Torino, Turin, \\ Italy \\ R. Pivonello \\ Dipartimento di Medicina Clinica e Chirurgia, Sezione di \\ Endocrinologia, Università Federico II, Naples, Italy
}


of assessing the published literature and the clinical experience with Pegvisomant. This group involved endocrinologists recognized experts in the field of acromegaly management and their understanding of the data reported so far worldwide as well as their recommendations for Pegvisomant use in clinical practice are presented here. Biochemical and clinical results of Pegvisomant, indications, treatment modalities, combination therapies, safety and regulatory and cost/efficacy issues were evaluated. Evidences were graded with GRADE system [1-3, 12, 13] based on the quality of evidence as very low quality (VLQ; expert opinion with one or a small number of small uncontrolled studies in support), low quality (LQ; large series of small uncontrolled studies), moderate quality (MQ; one or a small number of large uncontrolled studies or meta-analyses), or high quality (HQ; controlled studies or large series of large uncontrolled studies with sufficiently long follow-up). Recommendations were defined discretionary (DR) if based on VLQ-LQ evidence, or strong (SR) if supported by MQ-HQ evidence.

\section{What is Pegvisomant}

Pegvisomant is a drug designed to block the GH receptor (GHR) and, therefore, GH action. The discovery of this GHR antagonist was made possible by the elucidation of the structure-function relationship of $\mathrm{GH}$ and its receptor $[11,14]$. Growth hormone is a $22 \mathrm{kDa}$ polypeptide with 191 amino acids, two disulphide bonds and four alpha helices synthesized in the anterior pituitary and central to regulation of growth and differentiation. It has many other biological actions including enhancement of protein synthesis, lipolysis and hyperglycemic effects. Although GH may have direct effects on peripheral tissues most of its growth promoting effects are mediated by IGF-1 [15-17]. Growth hormone has two distinct domains (sites one and two) that interact with preformed GHR dimer on plasma membrane triggering conformational changes required for signaling [18]. The affinity of GH binding site one for GHR is high whereas the affinity of site two is lower. After initial high affinity binding at site one, subsequent binding at site two produces functional receptor dimerization. After the GH/GHR interaction, a series of intracellular signaling systems is mobilized, resulting in the activation or inactivation of genes responsible for $\mathrm{GH}$ action [19].

Pegvisomant is a $\mathrm{GH}$ analog with a single-aminoacid substitution at position 120 that generates the antagonist. Additional changes include amino acid substitutions within binding site 1 and a further modification by the addition of polyethylene glycol moieties [20]. The GHR antagonist acts by failing to induce proper or functional GHR dimerization. The pegylated [polyethylene glycol (PEG)] counterpart Pegvisomant is generated by the conjugation of GHR antagonist with four or five moieties of PEG 5000; PEG molecule addition increases the size of the antagonist and its serum half life from $\sim 30 \mathrm{~min}$ to more than $100 \mathrm{~h}$, by reducing renal clearance and intravascular proteolysis, and reduces immunogenicity of the molecule [21]. Like $\mathrm{GH}$, the GHR antagonist has a relatively small size $(22 \mathrm{kDa})$, and is normally cleared via the kidneys and/or GHR internalization [22].

\section{Biochemical outcomes in trials and observational registries}

Circulating $\mathrm{GH}$ values are not useful as biochemical marker of Pegvisomant effects in acromegaly both because endogenous $\mathrm{GH}$ secretion may increase during treatment due to negative feedback and, particularly, due to cross-reactivity of $\mathrm{GH}$ with Pegvisomant in most $\mathrm{GH}$ assays [21] (HQ). Therefore, GH should not be measured in monitoring Pegvisomant treatment (SR). Normalization of IGF-1 levels represents the main end point of Pegvisomant treatment (HQ) [23, 24] although sudden and remarkable $\mathrm{GH}$ increase during Pegvisomant therapy could be a marker of tumor re-growth [25] (VLQ). Many studies reported IGF-1 normalization or marked reduction in acromegaly patients treated with Pegvisomant [26] (HQ). In addition, improvement in quality of life was suggested even adding Pegvisomant in patients already effectively controlled by SRLs [27] (VLQ). However, reported effectiveness of Pegvisomant varied widely depending on the type of study (clinical trial vs. observational) as it happens with other medical therapies in acromegaly [3] (MQ). Indeed, serum IGF-1 levels normalized in more than $90 \%$ of patients particularly in initial clinical trials [28-32], while the control rate was lower in studies performed in the clinical setting and based on the retrospective analysis of disease-specific databases [33-39] (Table 1). Inadequate dose titration, poor compliance to daily injections, suboptimal selection of patients and technical problems related to IGF-1 assay could justify a lower than expected efficacy in "real life" conditions (VLQ), since the existence of a true "biochemical resistance" to Pegvisomant, as observed with SRLs [40], has not been clearly documented yet (VLQ). Effectiveness of Pegvisomant may be inversely correlated to baseline IGF-1 levels and starting dose should be higher and dose titration more rapid in patients with a worse endocrine profile (VLQ) [26, 41]. Better efficacy of Pegvisomant was associated with male gender, leanness, lower baseline GH and/or IGF-1 levels, previous irradiation, and related to treatment duration and appropriate dose titration (LQ) [37, 38, 41]. The role 
Table 1 Summary of biochemical results with Pegvisomant treatment in clinical trials and observational/retrospective studies in acromegaly

\begin{tabular}{|c|c|c|c|c|c|}
\hline Author & Primary end point & $\begin{array}{l}\text { N. of } \\
\text { patients }\end{array}$ & $\begin{array}{l}\text { Disease control } \\
(\%)\end{array}$ & Dose of Pegvisomant & $\begin{array}{l}\text { Duration of the } \\
\text { study }\end{array}$ \\
\hline \multicolumn{6}{|l|}{ Randomized clinical trials: } \\
\hline \multirow{2}{*}{$\begin{array}{l}\text { Herman-Bonert et al. } \\
\text { [28] }\end{array}$} & \multirow[t]{2}{*}{ IGF-1 normalization } & 3 & 100 & $30-80 \mathrm{mg} /$ weekly & 6 weeks \\
\hline & & 3 & 100 & 10-20 mg/day & 3 months \\
\hline \multirow[t]{4}{*}{ Trainer et al. [29] } & \multirow{4}{*}{$\begin{array}{l}\text { Dose-related } \\
\text { efficacy }\end{array}$} & \multirow[t]{4}{*}{109} & 10 & placebo & 33 months \\
\hline & & & 38 & $10 \mathrm{mg} /$ day & 3 months \\
\hline & & & 75 & $15 \mathrm{mg} /$ day & 3 months \\
\hline & & & 82 & $20 \mathrm{mg} /$ day & 3 months \\
\hline \multirow[t]{2}{*}{ van der Lely et al. [30] } & \multirow[t]{2}{*}{ IGF-1 normalization } & 90 & 97 & - & 12 months \\
\hline & & 62 & 92 & - & 18 months \\
\hline Drake et al. [31] & IGF-1 normalization & 7 & 100 & $20 \mathrm{mg} /$ day (median; range $15-40$ ) & 24 months \\
\hline Barkan et al. [32] & IGF-1 normalization & 49 & 78 & 16 mg/day (mean; range 5-40) & 8 months \\
\hline Colao et al. [26] & IGF-1 normalization & 12 & 75 & $25 \mathrm{mg} /$ day (median; range $10-40$ ) & 12 months \\
\hline \multicolumn{6}{|c|}{ Observational or retrospective studies: } \\
\hline \multirow[t]{3}{*}{ Schreiber et al. [33] } & \multirow[t]{3}{*}{ IGF-1 normalization } & 147 & 64 & \multirow[t]{3}{*}{$16.5 \mathrm{mg} /$ day (mean; range 10-50) } & 6 months \\
\hline & & 102 & 71 & & 12 months \\
\hline & & 39 & 76 & & 24 months \\
\hline Higham et al. [34] & IGF-1 normalization & 11 & 95 & 15 mg/day (median; range 10-60) & 91 months \\
\hline Trainer [35] & IGF-1 normalization & 792 & 62 & $\begin{array}{l}15 \mathrm{mg} / \text { day (median in controlled } \\
\text { patients) } \\
16 \mathrm{mg} / \text { day (median in not controlled } \\
\text { patients) }\end{array}$ & 60 months \\
\hline \multirow[t]{5}{*}{ Buchfelder et al. [36] } & \multirow[t]{5}{*}{ IGF-1 normalization } & 273 & 56 & \multirow[t]{5}{*}{$15 \mathrm{mg} /$ day (median) } & 6 months \\
\hline & & 202 & 71 & & 24 months \\
\hline & & 133 & 71 & & 36 months \\
\hline & & 71 & 65 & & 48 months \\
\hline & & 24 & 58 & & 60 months \\
\hline Marazuela et al. [37] & IGF-1 normalization & 44 & 84 & $\begin{array}{l}17 \pm 7 \mathrm{mg} / \text { day in men } 16 \pm 8 \mathrm{mg} / \text { day in } \\
\text { women }\end{array}$ & 23 months (mean) \\
\hline $\begin{array}{l}\text { Garsia Basavilbaso et al. } \\
\text { [38] }\end{array}$ & $\begin{array}{l}\text { Duration-related } \\
\text { efficacy }\end{array}$ & 28 & $\begin{array}{l}46 \\
59\end{array}$ & 9.6 mg/day (mean) & $\begin{array}{l}3 \text { months } \\
6 \text { months }\end{array}$ \\
\hline van der Lely et al. [39] & Safety and efficacy & 1288 & 63 & $\begin{array}{l}18 \mathrm{mg} / \text { day (mean in controlled patients) } \\
20 \mathrm{mg} / \text { day (mean in uncontrolled } \\
\text { patients) }\end{array}$ & 43 months (mean) \\
\hline
\end{tabular}

of d3GHR polymorphism, which could modify receptor sensitivity to GH [42], in response to Pegvisomant is still controversial (VLQ) [43-45]. Availability of validated assays is crucial for monitoring appropriately effectiveness of treatment and dose titration (SR). For this reason, IGF-1 values should be measured with the same method over time in each patient (SR). At present, considerable differences exist among available assays, due to lack of standardization, use of different types of antibodies and interference of binding proteins (MQ) [46]. Moreover, specific age-related normative intervals are rarely obtained, as recommended by available general guidelines [10], in local populations by centralized laboratories
(LQ). Finally, given the within-individual biological variation of IGF-1 assays caution should be also used in interpreting values close to reference limits even if obtained with the same method [47, 48] (DR).

\section{Peripheral and tissue effects of Pegvisomant}

Treatment with Pegvisomant improves clinical syndrome of acromegaly in a high percentage of patients (HQ), positively impacts glucose metabolism (MQ), quality of life (MQ) and cardiovascular and skeletal complications (MQ) [49] (Table 2). 
Glucose and lipid metabolism

In acromegaly, abnormal glucose tolerance, insulin resistance, hyperinsulinemia and diabetes mellitus are frequently observed [50] (HQ). Medical treatment of acromegaly may variably influence glucose metabolism. It is known that SRLs inhibit insulin secretion, inducing a possibly negative impact on glucose homeostasis (MQ) [51], whereas Pegvisomant improves insulin sensitivity likely by ameliorating IGF-1 excess and its effect on insulin resistance (MQ) [33, 52-57]. Several studies demonstrated that Pegvisomant monotherapy induced a

Table 2 Clinical and comorbidity outcomes of Pegvisomant therapy in acromegaly

\begin{tabular}{|c|c|c|}
\hline Endpoints & Results & References \\
\hline \multicolumn{3}{|l|}{ Glucose metabolism } \\
\hline Fasting glucose levels & $\left.\right|^{*}$ & {$[52-54]$} \\
\hline Glucose tolerance & $\hat{\varphi}^{*}$ & {$[53,58]$} \\
\hline $\mathrm{HbA} 1 \mathrm{c} \%$ & $\perp^{*}$ & {$[33,53]$} \\
\hline Insulin sensitivity & $4^{*}$ & {$[52,55-57]$} \\
\hline HOMA index & $\perp$ & {$[52,55]$} \\
\hline \multicolumn{3}{|l|}{ Lipid metabolism } \\
\hline Total cholesterol & $4 /=$ & {$[59,60] /[26,61]$} \\
\hline LDL cholesterol & $4 /=$ & {$[59,60] /[26,61]$} \\
\hline Triglyceride & $=$ & {$[59,60] /[26,61]$} \\
\hline Lipoprotein (a) & $\perp^{*}$ & {$[59,60]$} \\
\hline \multicolumn{3}{|l|}{ Cardiovascular complications } \\
\hline Cardiac mass & * & {$[63]$} \\
\hline Systolic and diastolic function & $4^{*}$ & [63] \\
\hline Rhythm disturbances & |* & [64] \\
\hline Blood pressure & $\left.\right|^{*}$ & {$[26,61]$} \\
\hline Framingham risk score & $1^{*}$ & [61] \\
\hline Carotid arteries wall thickness & 1 & [65] \\
\hline Brachial arteries vascular function & $\perp^{*}$ & [65] \\
\hline \multicolumn{3}{|l|}{ Skeletal complications } \\
\hline Bone turn-over & $\mid$ * & {$[71,72]$} \\
\hline BMD & $4^{*}$ & [73] \\
\hline
\end{tabular}

* Denote significant change significant decrease in fasting glucose levels and $\mathrm{HbA1c}$ $[33,52-54,58]$ also in patients with diabetes mellitus and impaired glucose tolerance (MQ). A positive impact of Pegvisomant on peripheral insulin sensitivity was also demonstrated [52, 55-57] (MQ). However, a substantial proportion of patients included in these studies were resistant to SRLs; therefore, improved glucose metabolism could derive from better biochemical control and/or to removed inhibitory effect of SRLs on insulin secretion [58] (VLQ). Variable results were observed on lipid metabolism after Pegvisomant. An increase in total and LDL cholesterol with unchanged triglyceride levels and a significant decline in lipoprotein (a) levels was observed [59, 60], whereas other authors $[24,61]$ reported that lipid profile did not change during Pegvisomant therapy (LQ).

\section{Cardiovascular and skeletal complications}

Acromegaly is associated with a specific cardiomyopathy, characterized by biventricular hypertrophy and complicated by initial diastolic dysfunction and late systolic dysfunction, potentially leading to heart failure (HQ) [62]. Furthermore, systemic arterial hypertension, frequently associated with the disease, contributes to worsening acromegalic cardiomyopathy [62]. Long-term (18 months) treatment with Pegvisomant induced a significant reduction of cardiac mass and significant improvement of diastolic and systolic function in patients with acromegaly mostly resistant to SRLs (LQ) [63]. Treatment with Pegvisomant could also exert beneficial effects on rhythm disorders and hyperkinetic syndrome (LQ) [64]. Moreover, 12 months of Pegvisomant therapy were associated with improved blood pressure, particularly of diastolic values, in hypertensive patients [24, 61] (LQ). IGF-I normalization significantly lowered predicted cardiovascular risk, calculated with the Framingham risk score [61] (LQ). On Pegvisomant slight reduction of carotid arteries wall thickness and significant improvement of brachial arteries vascular function in patients with acromegaly resistant to SRLs were reported (VLQ) [65].

Growth hormone and IGF-I play a significant role in the regulation of bone metabolism [66, 67] (HQ). Acromegaly increases risk of vertebral fractures not necessarily associated with reduced bone mass (MQ) [68-70] but with increased bone turn-over which normalized during 6 months of Pegvisomant treatment [71, 72] (LQ). Longterm treatment with Pegvisomant also induced a significant increase of bone mineral density in active acromegaly (LQ) [73]. Although Pegvisomant use was weakly associated with an increased rate of fractures this has been attributed to global increased severity of the disease in treated patients [70] (LQ). 


\section{Indications}

Pegvisomant is traditionally indicated for treatment of acromegaly patients with inadequate response to pituitary adenomectomy or radiation therapy, or for those intolerant or resistant to SRLs (HQ). However, a clear-cut definition of resistance to SRLs is missing (VLQ) [74]. In fact, during SRL therapy biochemical control is defined as random basal $\mathrm{GH}$ lower than $1 \mathrm{mcg} / \mathrm{liter}$ and IGF-1 levels below the upper limit of normal range for age (MQ) [3]. Using these strict criteria [10] normalization of biochemical activity in unselected patients with acromegaly after long-term (>6-12 months) treatment with maximal SRL doses occurs approximately in 25-50\% of cases [3, 75-77] (MQ). Non-responders to SRL therapy (minimal effect on GH and IGF-I levels and on tumor shrinkage) should be switched to Pegvisomant (SR). In partial responders to SRLs, Pegvisomant monotherapy or combination therapy with Pegvisomant and SRL should be considered (DR). Tumor shrinkage quite frequently (around $50 \%$ of treated patients) occurs during therapy with SRLs often but not necessarily together with biochemical normalization [78-80] (MQ). Interestingly, in patients with acromegaly and McCune Albright syndrome surgery and even radiation therapy often can not be performed [81] and SRLs have very low chances to be effective [81] (LQ). In these patients, Pegvisomant can be considered as primary treatment (DR). Moreover, primary post-surgical medical treatment with Pegvisomant should be considered in patients already proven to be resistant to SRLs as those who underwent a sufficiently long ( $>3-6$ months) trial of presurgical SRL treatment which demonstrated to be ineffective in controlling $\mathrm{GH}$ and IGF-1 (unless a $>75 \%$ surgical debulking is achieved [82]) (DR). Primary postsurgical Pegvisomant treatment can be considered in patients after irradiation in whom elevated IGF-1 levels may persist for long time but likelihood of tumor regrowth is modest [1] (DR) and in patients with poorly controlled diabetes mellitus in whom SRLs may potentially worsen glucose metabolism [51-54] (DR).

\section{Treatment modalities}

Pegvisomant is administered by subcutaneous injections. Ten, 15, and $20 \mathrm{mg}$ per vial are available dosages. Initially, treatment regimens contemplated a $40-80 \mathrm{mg}$ loading dose. In clinical practice this procedure has not proven to be useful and has been abandoned (LQ) [23]. Daily administration is the most effective because it achieves higher serum Pegvisomant concentrations with a lower dose of drug (MQ) [29, 83]. The target of therapy is to achieve serum IGF-I in the middle of age-related reference range (MQ) [11]. Starting dose is usually $10 \mathrm{mg} /$ day and maximum maintenance dose which currently can be administered based on regulatory indications is $30 \mathrm{mg}$ daily (LQ) [84]. For patients who require a dose $>20 \mathrm{mg}$ daily, Pegvisomant treatment is more inconvenient due to daily multiple injections (VLQ) [85]. After treatment start, serum IGF-I levels fall within 2 weeks and then reach a plateau after 4 weeks (HQ) [29]. Consequently, it is suggested to measure IGF-I 4 to 6 weeks after beginning treatment and after every change of dose until biochemical control is reached (DR). Once serum IGF-I levels are normalized, they should be monitored every 3-6 months [38] since Pegvisomant dose may require up- or down-titration in the same individual during treatment (DR) [3].

\section{Combination therapies}

Dopamine agonists

Cabergoline, a dopamine receptor agonist, has limited activity when used as monotherapy in acromegaly (MQ) [86, 87]. However, its combination with SRLs was shown to be effective in some patients (LQ) [86]. Few data are available regarding the combination of cabergoline and Pegvisomant. However, it was reported that addition of Pegvisomant to cabergoline as well as of cabergoline to Pegvisomant may result in improved IGF-1 control (LQ) [88, 89]. A better response was associated with baseline IGF-1 levels not higher than $160 \%$ of ULN. No correlation was found with baseline prolactin levels. The combined treatment was well tolerated and safe (LQ).

Somatostatin receptor ligands

When compared with monotherapy, combination treatment with SRLs may require a lower dose (even in only 1 weekly administration) of Pegvisomant to obtain similar efficacy (MQ) (Table 3) [90-93]. This is due to different mechanisms, including elevation of serum Pegvisomant levels [93], reduced insulin concentration in the portal vein, which decreases the number of available liver $\mathrm{GH}$ receptors [94] and reduced endogenous GH levels (LQ). In all reported trials, combination treatment was generally well tolerated (LQ). However, transient liver function test abnormalities were observed in a variable percentage of cases (11-38\%), apparently higher when compared with monotherapy. Significant tumor shrinkage during combined treatment was observed in 13-19\% of patients [95]. Glucose metabolism was not substantially affected [96]. 


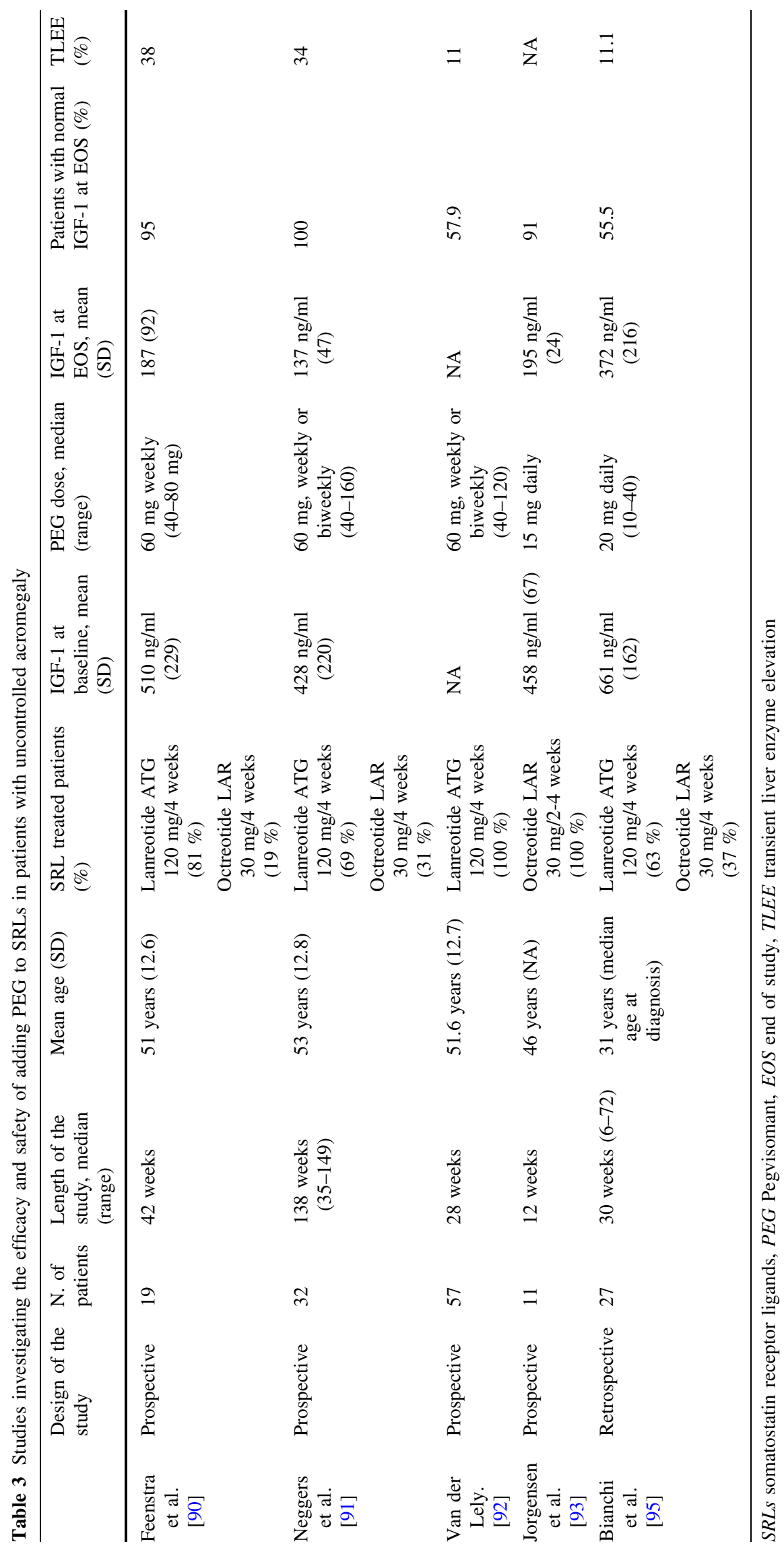




\section{General and tumor growth safety}

General safety

In clinical trials, Pegvisomant has been shown to be generally safe and well tolerated [29, 30] (HQ). In a global non-interventional surveillance study (1,288 subjects, mean duration 3.7 years) Pegvisomant-related adverse events (AE) (changes in tumor size, increase in liver enzymes, and injection site reactions) were recorded in $9.6 \%$ of subjects [39]. In all studies, mortality was not related to Pegvisomant use (MQ). Injection-site reactions were initially reported with a frequency up to $11 \%$ and were generally mild, erythematous, self-limited and did not require treatment [29, 30]. Lipodistrophy during Pegvisomant therapy was sporadically reported likely due to local lypolitic GH inhibition (LQ). Frequent rotation of injection sites could prevent local reactions and patients should be carefully monitored and trained [97, 98] (SR). Surveillance studies [33, 98] reported an elevation of liver transaminase levels $>3$ times ULN in about $5-8 \%$ of patients mainly previously treated with SRLs. Transaminase level elevations during Pegvisomant treatment were often mild and transient, did not appear to be dose-related (idiosyncratic drug toxicity?) and occurred within the first year of treatment (MQ). Rare cases of drug-induced hepatitis (but not liver failure) were reported (VLQ) [99]. When Pegvisomant was combined with SRLs, transient liver enzyme elevations seemed to be 2-3 times more frequent (MQ) [33, 39, 82, 99-103]. Controversial is the correlation between diabetes mellitus and elevated transaminase levels (VLQ) [33, $92,99,101]$. A common polymorphism found in Gilbert's syndrome was associated with Pegvisomantinduced liver injury [104]. Biliary complications may arise from restitution to normal of gallbladder motility after cessation of SRL treatment [10]. We recommend not to start Pegvisomant if there is a liver dysfunction (SR). Liver function should be evaluated monthly for at least 6 months after initiating therapy, quarterly for next 6 months, and then semi-annually (SR). If transaminases increase $>5$ times ULN or $>3$ times ULN with increased serum bilirubin Pegvisomant must be discontinued (SR). If transaminases increase $<3$ times ULN without signs or symptoms of liver failure Pegvisomant could be continued (DR), but they must be monitored weekly (SR) [24, 29, 33]. Since Pegvisomant may improve glucose tolerance, glucose levels should be monitored particularly in first months of treatment and anti-diabetic drugs adjusted if necessary (DR) [30, 33].
Tumor growth safety

Only 1 out of 43 subjects treated with Pegvisomant for 29 months and monitored for 58 months, showed an increase in pituitary tumor volume [105]. In the German Pegvisomant Observational Study [106] in 18 out of 307 $(5.9 \%)$ patients treated with Pegvisomant for an average of 86 weeks tumor size increased; however, after centralized image re-evaluation, tumor progression was confirmed in only eight patients ( $3 \%$ ). Among 61 patients observed by Buhk et al. [107], in 3 (4.9\%) increased tumor volume $>25 \%$ during the first year of therapy was reported. Marazuela et al. [37] observed significant increased tumor size in $6.7 \%$ of subjects (5 of 75), followed for $29 \pm 20$ months; absence of previous irradiation and shorter duration of pre-Pegvisomant SRL therapy were associated with increased risk of growth (LQ). In the global surveillance study [39] incidence of increased pituitary tumor size was $7.2 \%$ (67 of 936) in the local MRI reading, while again it was only $3.2 \%$ (45 of 936) in the central reading. Thus, a careful serial evaluation of all available images is necessary to avoid misinterpretations (SR) [39, 106]. Therefore, tumor growth, observed more frequently during the first year of treatment, may prevalently reflect the disease natural history $[24,30]$ or the consequence of SRL discontinuation [106]. On the contrary, irradiation seems to be associated with a reduction in tumor size [24, 105, 108]. All patients treated with Pegvisomant should undergo regular sellar MRI to screen for potential tumor growth (SR). A more intensive MRI follow-up protocol should be followed in non-irradiated patients (DR).

\section{Regulatory and cost/efficacy issues}

\section{Regulatory issues}

Pegvisomant was licensed for the treatment of acromegaly in 2002 by EMA (EU, European Medicines Agency) and in 2003 by FDA (US, Food and Drug Administration). Label indications in EU limit use of Pegvisomant to patients with acromegaly with inadequate response to surgery and/or radiation therapy and in whom medical treatment with SRLs did not normalize IGF-I or was not tolerated (third line therapy). Label indications in US indicate Pegvisomant in acromegaly patients with inadequate response to surgery and/or radiation therapy and/or other medical therapies, or for whom these therapies are not appropriate (first/second line therapy in specific cases) better reflecting available guidelines (MQ) [1-3]. Pegvisomant should be prescribed 
by doctors with expertise in acromegaly management (MQ). National and regional regulatory agencies provide largely variable criteria to allow centers for prescription (VLQ). First injection of Pegvisomant should be done under close medical supervision (SR) and specific warnings about systemic hypersensitivity reactions were recently added in the package leaflet. Injections less frequently than daily normalize IGF-I levels in some patients [108] and in Acrostudy [39] $12 \%$ of clinicians did not use daily injections (VLQ). Combination therapy Pegvisomant + SRLs is not recommended by EMA though the Agency recognized the interest for the complementary actions of these drugs. Pegvisomant in combination therapy is considered an "off-label" use by some local regulatory agencies. Pegvisomant should not be used during pregnancy unless clearly necessary according to EMA and FDA (MQ) (pregnancy class B). In fact, there are only few reports about its safety in pregnancy [109].

\section{Cost/efficacy analysis}

Pegvisomant is an effective but expensive drug (MQ). Certainly, the direct costs of neurosurgery, dopaminergic agents, SRLs and radiotherapy are lower than lifelong Pegvisomant treatment, but standard therapies do not provide biochemical normalization in some patients (HQ). On the other hand, control of disease is associated with normalized mortality rate and improvement of comorbidities (HQ) [1-3]. In addition, burden of direct and indirect (associated comorbidities and loss of working days) costs is higher in patients with acromegaly not controlled by standard therapies (MQ) $[110,111]$. Therefore, if Pegvisomant is prescribed according to licensed use it may be cost-effective considering relative rarity of acromegaly (MQ). Nevertheless, according to a pharmacoeconomic model [112] the best cost-effectiveness ratio could be reached with Pegvisomant price reduced by about one-third (VLQ).

\section{Summary of recommendations}

Place of Pegvisomant in guidelines

\section{Primary treatment}

Pegvisomant cannot be recommended as primary treatment of the general acromegaly population (SR). In fact, surgery (performed by an experienced neurosurgeon) remains the primary treatment option in patients with acromegaly with totally resectable tumor (SR). Moreover, SRLs are primary medical treatment if surgery is contraindicated, not accepted by the patient or in case of poor likelihood of total surgical resection (SR). When surgery and radiation therapy cannot be performed and SRL are unlikely to be, or may not be, effective as in patients with acromegaly and McCune Albright syndrome or empty sella [113] Pegvisomant could be considered as primary treatment option (DR).

\section{First-line (post-surgery) pharmacologic treatment}

SRLs are primary first-line therapy after surgery (SR). Primary postsurgical therapy with cabergoline may be considered particularly in patients with relatively mild disease [114] (DR). There are at least three circumstances in which primary postsurgical medical treatment with Pegvisomant could be considered (DR): (1) patients who underwent a sufficiently long ( $>3-6$ months) trial of presurgical SRL treatment [3] that was ineffective in controlling GH and IGF-1 and in whom mass effect of residual tumor is not an issue; (2) patients with residual tumor in whom radiation treatment is given as second option: in fact, after radiation elevated IGF-1 levels may persist for long time but likelihood of tumor regrowth is modest [1]; (3) patients with poorly controlled diabetes mellitus in whom SRL treatment may potentially worsen glucose metabolism [51-54].

\section{Second-line pharmacologic treatment}

Partial (GH and IGF-I decreased but not normalized) or no response (minimal changes in GH and IGF-1) to SRLs may be observed (HQ) [3]. Patients with no response after an adequately long (6-12 months) period of treatment with maximal doses of SRL should be switched to Pegvisomant monotherapy (SR). If biochemical control is not achieved Pegvisomant dose should be increased (SR) and/or combination treatment with dopamine agonists should be given (DR). In patients who do not achieve biochemical control of the disease [7] but have documented partial response to SRLs ( $>50 \%$ reduction of GH and IGF-1 vs. baseline and/ or tumor shrinkage $>20 \%$ ) either switching to Pegvisomant monotherapy or combination therapy Pegvisomant + SRL should be considered (DR). If SRL + Pegvisomant combination is not effective a possible alternative could be association of Pegvisomant with dopamine agonists (DR) [3] (Fig. 1). Patients seldom do not tolerate SRL treatment for gastrointestinal side effects (LQ) [115]: these subjects should be switched to Pegvisomant monotherapy regardless biochemical efficacy of SRL (taking into account potential mass effect) (SR).

Dose, efficacy and safety monitoring

Individual optimal dose of Pegvisomant may vary according to anthropometric and genetic characteristics 


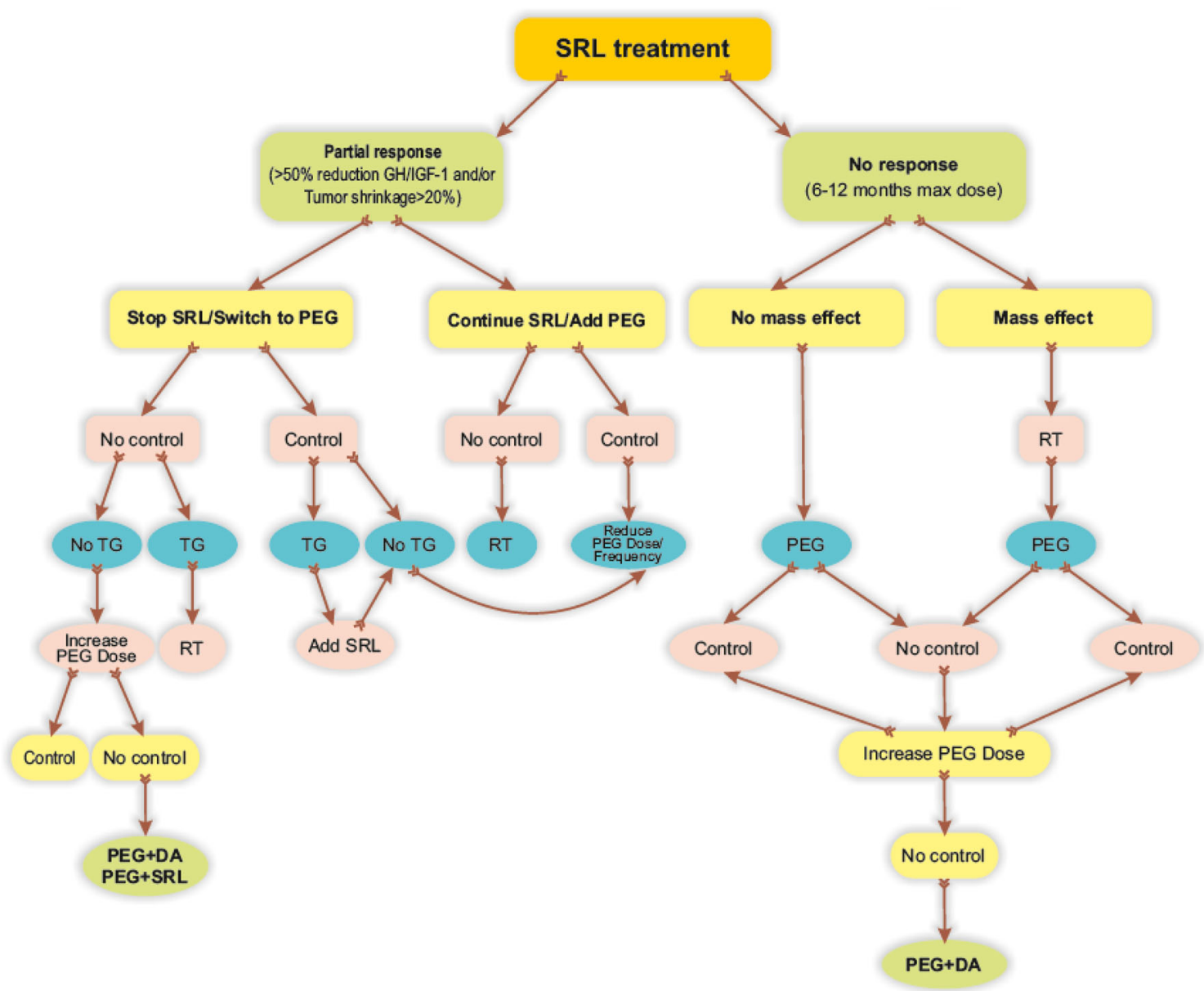

Fig. 1 Proposed algorithm for the use of Pegvisomant in acromegaly patients partially or not responder to SRLs. SRL somatostatin receptor ligands, $P E G$ Pegvisomant, $R T$ radiation therapy, $T G$ tumor growth, $D A$ dopamine agonists

(VLQ). Recommended starting dose is $10 \mathrm{mg} /$ day s.c. (DR). An initial load dose of Pegvisomant is not recommended (DR). Doses of Pegvisomant exceeding $30 \mathrm{mg} / \mathrm{day}$ are not recommended although in biochemically and clinically persistently active disease with no other treatment choice a further dose increase to $40 \mathrm{mg} /$ day could be considered (DR).

Growth hormone should not be measured to assess effects of Pegvisomant (SR). Goal of Pegvisomant treatment is to normalize circulating IGF-1 levels (SR). Biochemical effects of Pegvisomant should be checked in laboratories with experience in IGF-1 measurement which give reference values divided by decade of age (SR). Patients with deranged glucose homeostasis on SRLs should be switched to Pegvisomant (DR). SRL treatment is known to counteract myocardial hypertrophy in patients with acromegaly [116] (HQ). Pegvisomant was also associated with positive cardiovascular effects and acromegaly cardiopathy does not contraindicate Pegvisomant (SR). Pegvisomant is the only treatment which was shown to normalize bone turnover in acromegaly [71] and prevalent vertebral fractures do not contraindicate Pegvisomant (DR).

Patients with known liver dysfunction should not be initiated with Pegvisomant (SR). Liver function should be evaluated periodically during therapy (SR). Injection-site reactions, such as lipodystrophy or lipohypertrophy may rarely occur and frequent rotation of injection sites is recommended (SR). Unlike SRLs [78-80] Pegvisomant treatment does not target tumor (HQ). Therefore, regular MRI monitoring is required (SR).

Acknowledgments The authors are indebted to the following colleagues for their assistance in the preparation of manuscript as well as for the fruitful discussion: Donato Iacovazzo (Rome), Elena Malchiodi (Milano), Gherardo Mazziotti (Brescia), Nunzia Prencipe (Torino), Soraya Puglisi (Messina), Paola Sartorato (Montebelluna) and Ludovica Francesca Stella Grasso (Naples). The authors would like to thank SIE President and Guidelines Committee for their helpful support.

Conflict of interest A.Giustina is consultant for Ipsen, Novartis and Pfizer; F. Bogazzi is member of Acrostudy Board and recipient of 
research grant from Pfizer; S. Cannavo' is speaker and member of scientific board for Eli Lilly, Italfarmaco and Viropharma; E. De Menis is speaker for Ipsen and Pfizer; S. Grottoli is recipient of research grant and support from Ipsen, Italfarmaco, Novartis and Pfizer; R. Pivonello has been principal investigator of research studies from Novartis, is recipient of research grants from Novartis, Pfizer, Viropharma and IBSA, is consultant for Novartis, Ipsen, Pfizer, Viropharma, Ferring and Italfarmaco, and speaker for Novartis. M.R. Ambrosio, P. Beck Peccoz, L. De Marinis have nothing to disclose.

Open Access This article is distributed under the terms of the Creative Commons Attribution License which permits any use, distribution, and reproduction in any medium, provided the original author(s) and the source are credited.

\section{References}

1. Melmed S, Colao A, Barkan A, Molitch M, Grossman AB, Kleinberg D, Clemmons D, Chanson P, Laws E, Schlechte J, Vance ML, Ho K, Giustina A, Acromegaly Consensus Group (2009) Guidelines for acromegaly management: an update. J Clin Endocrinol Metab 94:1509-1517

2. Melmed S, Casanueva F, Cavagnini F, Chanson P, Frohman LA, Gaillard R, Ghigo E, Ho K, Jaquet P, Kleinberg D, Lamberts S, Laws E, Lombardi G, Sheppard MC, Thorner M, Vance ML, Wass JA, Giustina A (2005) Consensus statement: medical management of acromegaly. Eur J Endocrinol 153:737-740

3. Giustina A, Chanson P, Kleinberg D, Bronstein MD, Clemmons DR, Klibanski A, van der Lely AJ, Strasburger CJ, Lamberts SW, Ho KK, Casanueva FF, Melmed S (2014) A consensus on the medical treatment of acromegaly. Nat Rev Endocrinol 10:243-248

4. Melmed S (2009) Acromegaly pathogenesis and treatment. J Clin Invest 119:3189-3202

5. Giustina A, Bronstein MD, Casanueva FF, Chanson P, Ghigo E, Ho KK, Klibanski A, Lamberts S, Trainer P, Melmed S (2011) Current management practices for acromegaly: an international survey. Pituitary 14:125-133

6. Giustina A, Casanueva FF, Cavagnini F, Chanson P, Clemmons D, Frohman LA, Gaillard R, Ho K, Jaquet P, Kleinberg DL, Lamberts SW, Lombardi G, Sheppard M, Strasburger CJ, Vance ML, Wass JA, Melmed S, Pituitary Society and the European Neuroendocrine Association (2003) Diagnosis and treatment of acromegaly complications. J Endocrinol Invest 26:1242-1247

7. Melmed S, Casanueva FF, Klibanski A, Bronstein MD, Chanson P, Lamberts SW, Strasburger CJ, Wass JA, Giustina A (2013) A consensus on the diagnosis and treatment of acromegaly complications. Pituitary 16:294-302

8. Holdaway IM, Bolland MJ, Gamble GD (2008) A meta-analysis of the effect of lowering serum levels of GH and IGF-I on mortality in acromegaly. Eur J Endocrinol 159:89-95

9. Giustina A, Barkan A, Casanueva FF, Cavagnini F, Frohman L, Ho K, Veldhuis J, Wass J, Von Werder K, Melmed S (2000) Criteria for cure of acromegaly: a consensus statement. J Clin Endocrinol Metab 85:526-529

10. Giustina A, Chanson P, Bronstein MD, Klibanski A, Lamberts S, Casanueva FF, Trainer P, Ghigo E, Ho K, Melmed S, Acromegaly Consensus Group (2010) A consensus on criteria for cure of acromegaly. J Clin Endocrinol Metab 95:3141-3148

11. Kopchick JJ, Parkinson C, Stevens EC, Trainer PJ (2002) Growth hormone receptor antagonists: discovery, development, and use in patients with acromegaly. Endocr Rev 23:623-646

12. Funder JW, Carey RM, Fardella C, Gomez-Sanchez CE, Mantero F, Stowasser M, Young WF Jr, Montori VM, Endocrine
Society (2008) Case detection, diagnosis, and treatment of patients with primary aldosteronism: an endocrine society clinical practice guideline. J Clin Endocrinol Metab 93:3266-3281

13. Guyatt GH, Oxman AD, Vist GE, Kunz R, Falck-Ytter Y, Alonso-Coello P, Schünemann HJ, GRADE Working Group (2008) GRADE: an emerging consensus on rating quality of evidence and strength of recommendations. BMJ 336:924-926

14. Kopchick JJ, List EO, Kelder B, Gosney ES, Berryman DE (2014) Evaluation of growth hormone $(\mathrm{GH})$ action in mice: discovery of GH receptor antagonists and clinical indications. Mol Cell Endocrinol 386:34-45

15. Giustina A, Veldhuis JD (1998) Pathophysiology of the neuroregulation of growth hormone secretion in experimental animals and the human. Endocr Rev 19:717-797

16. Mazziotti G, Giustina A (2013) Glucocorticoids and the regulation of growth hormone secretion. Nat Rev Endocrinol 9:265-276

17. Kamenický P, Mazziotti G, Lombès M, Giustina A, Chanson P (2014) Growth hormone, insulin-like growth factor-1, and the kidney: pathophysiological and clinical implications. Endocr Rev 35:234-281

18. Ross RJM, Leung KC, Maamra M, Bennett W, Doyle N, Waters MJ, Ho KKY (2001) Binding and functional studies with the growth hormone receptor antagonist B2036-PEG (Pegvisomant), reveal effects of pegylation and evidence that it binds to a receptor dimer. J Clin Endocrinol Metab 86:1716-1723

19. de Vos AM, Ultsch M, Kossiakoff AA (1992) Human growth hormone and extracellular domain of its receptor: crystal structure of the complex. Science 255:306-331

20. Carter-Su C, Rui L, Herrington J (2000) Role of the tyrosine kinase JAK2 in signal transduction by growth hormone. Pediatr Nephrol 14:550-557

21. Muller AF, Kopchick JJ, Flyvbjerg A, Van Der Lely AJ (2004) Growth hormone receptor antagonists. J Clin Endocrinol Metab 89:1503-1511

22. Maamra M, Kopchick JJ, Strasburger CJ, Ross RJM (2004) Pegvisomant, a growth hormone-specific antagonist, undergoes cellular internalization. J Clin Endocrinol Metab 89:4532-4537

23. Colao A, Arnaldi G, Beck-Peccoz P, Cannavò S, Cozzi R, Degli Uberti E, De Marinis L, De Menis E, Ferone D, Gasco V, Giustina A, Grottoli S, Lombardi G, Maffei P, Martino E, Minuto F, Pivonello R, Ghigo E (2007) Pegvisomant in acromegaly: why, when, how. J Endocrinol Invest 30:693-699

24. Hodish I, Barkan A (2008) Long-term effects of Pegvisomant in patients with acromegaly. Nat Clin Pract Endocrinol Metab 4:324-332

25. Marazuela M, Paniagua AE, Gahete MD, Lucas T, AlvarezEscolá C, Manzanares R, Cameselle-Teijeiro J, Luque-Ramirez M, Luque RM, Fernandez-Rodriguez E, Castaño JP, Bernabeu I (2011) Somatotroph tumor progression during Pegvisomant therapy: a clinical and molecular study. J Clin Endocrinol Metab 96:E251-E259

26. Colao A, Pivonello R, Auriemma RS, De Martino MC, Bidlingmaier M, Briganti F, Tortora F, Burman P, Kourides IA, Strasburger CJ, Lombardi G (2006) Efficacy of 12-month treatment with the GH receptor antagonist Pegvisomant in patients with acromegaly resistant to long-term, high-dose somatostatin analog treatment: effect on IGF-I levels, tumor mass, hypertension and glucose tolerance. Eur J Endocrinol 154:467-477

27. Neggers SJ, van Aken MO, de Herder WW, Feelders RA, Janssen JA, Badia X, Webb SM, van der Lely AJ (2008) Quality of life in acromegalic patients during long-term somatostatin analog treatment with and without Pegvisomant. J Clin Endocrinol Metab 93:3853-3859

28. Herman-Bonert VS, Zib K, Scarlett JA, Melmed S (2000) Growth hormone receptor antagonist therapy in acromegalic 
patients resistant to somatostatin analogs. J Clin Endocrinol Metab 85:2958-2961

29. Trainer PJ, Drake WM, Katznelson L, Freda PU, HermanBonert V, van der Lely AJ, Dimaraki EV, Stewart PM, Friend KE, Vance ML, Besser GM, Scarlett JA, Thorner MO, Parkinson C, Klibanski A, Powell JS, Barkan AL, Sheppard MC, Malsonado M, Rose DR, Clemmons DR, Johannsson G, Bengtsson BA, Stavrou S, Kleinberg DL, Cook DM, Phillips LS, Bidlingmaier M, Strasburger CJ, Hackett S, Zib K, Bennett WF, Davis RJ (2000) Treatment of acromegaly with the growth hormone-receptor antagonist Pegvisomant. N Engl J Med 342:1171-1177

30. van der Lely AJ, Hutson RK, Trainer PJ, Besser GM, Barkan AL, Katznelson L, Klibanski A, Herman-Bonert V, Melmed S, Vance ML, Freda PU, Stewart PM, Friend KE, Clemmons DR, Johannsson G, Stavrou S, Cook DM, Phillips LS, Strasburger CJ, Hackett S, Zib KA, Davis RJ, Scarlett JA, Thorner MO (2001) Long-term treatment of acromegaly with Pegvisomant, a growth hormone receptor antagonist. Lancet 358:1754-1759

31. Drake WM, Parkinson C, Akker SA, Monson JP, Besser GM, Trainer PJ (2001) Successful treatment of resistant acromegaly with a growth hormone receptor antagonist. Eur J Endocrinol 145:451-456

32. Barkan AL, Burman P, Clemmons DR, Drake WM, Gagel RF, Harris PE, Trainer PJ, van der Lely AJ, Vance ML (2005) Glucose homeostasis and safety in patients with acromegaly converted from long-acting octreotide to Pegvisomant. J Clin Endocrinol Metab 90:5684-5691

33. Schreiber I, Buchfelder M, Droste M, Forssmann K, Mann K, Saller B, Strasburger CJ, German Pegvisomant Investigators (2007) German Pegvisomant Investigators. Treatment of acromegaly with the GH receptor antagonist Pegvisomant in clinical practice: safety and efficacy evaluation from the German Pegvisomant Observational Study. Eur J Endocrinol 156:75-82

34. Higham CE, Chung TT, Lawranc J, Drake WM, Trainer PJ (2009) Long-term experience of Pegvisomant therapy as a treatment for acromegaly. Clin Endocrinol 71:86-91

35. Trainer PJ (2009) ACROSTUDY: the first 5 years. Eur J Endocrinol 161(Suppl 1):S19-S24

36. Buchfelder M, Schlaffer S, Droste M, Mann K, Saller B, Brübach K, Stalla GK, Strasburger CJ, German Pegvisomant Observational Study (2009) The German ACROSTUDY: past and present. Eur J Endocrinol 161(Suppl 1):S3-S10

37. Marazuela M, Lucas T, Alvarez-Escolá C, Puig-Domingo M, de la Torre NG, de Miguel-Novoa P, Duran-Hervada A, Manzanares R, Luque-Ramírez M, Halperin I, Casanueva FF, Bernabeu I (2009) Long-term treatment of acromegalic patients resistant to somatostatin analogues with the $\mathrm{GH}$ receptor antagonist Pegvisomant: its efficacy in relation to gender and previous radiotherapy. Eur J Endocrinol 160:535-542

38. García Basavilbaso N, Guitelman M, Nagelberg A, Stalldecker G, Carabelli A, Bruno O, Danilowitz K, Manavela M, Mallea Gil S, Ballarino C, Guelman R, Katz D, Fidalgo S, Leal R, Fideleff H, Servidio M, Bruera D, Librandi F, Chervin A, Vitale M, Basso A (2010) Experience from the Argentine Pegvisomant Observational Study: preliminary data. Front Horm Res 38:42-49

39. van der Lely AJ, Biller BM, Brue T, Buchfelder M, Ghigo E, Gomez R, Hey-Hadavi J, Lundgren F, Rajicic N, Strasburger CJ, Webb SM, Koltowska-Häggström M (2012) Long-term safety of Pegvisomant in patients with acromegaly: comprehensive review of 1288 subjects in ACROSTUDY. J Clin Endocrinol Metab 97:1589-1597

40. Gola M, Bonadonna S, Mazziotti G, Amato G, Giustina A (2006) Resistance to somatostatin analogs in acromegaly: an evolving concept? J Endocrinol Invest 29:86-93
41. Parkinson C, Burman P, Messig M, Trainer PJ (2007) Gender, body weight, disease activity, and previous radiotherapy influence the response to Pegvisomant. J Clin Endocrinol Metab 92:190-195

42. Bianchi A, Giustina A, Cimino V, Pola R, Angelini F, Pontecorvi A, De Marinis L (2009) Influence of growth hormone receptor $\mathrm{d} 3$ and full-length isoforms on biochemical treatment outcomes in acromegaly. $\mathrm{J}$ Clin Endocrinol Metab 94:2015-2022

43. Bianchi A, Mazziotti G, Tilaro L, Cimino V, Veltri F, Gaetani E, Pecorini G, Pontecorvi A, Giustina A, De Marinis L (2009) Growth hormone receptor polymorphism and the effects of Pegvisomant in acromegaly. Pituitary 12:196-199

44. Bernabeu I, Alvarez-Escolá C, Quinteiro C, Lucas T, Puig-Domingo M, Luque-Ramírez M, de Miguel-Novoa P, FernandezRodriguez E, Halperin I, Loidi L, Casanueva FF, Marazuela M (2010) The exon 3-deleted growth hormone receptor is associated with better response to Pegvisomant therapy in acromegaly. J Clin Endocrinol Metab 95:222-229

45. Filopanti M, Olgiati L, Mantovani G, Corbetta S, Arosio M, Gasco V, De Marinis L, Martini C, Bogazzi F, Cannavò S, Colao A, Ferone D, Arnaldi G, Pigliaru F, Peri A, Angeletti G, Jaffrain-Rea ML, Lania AG, Spada A (2012) Growth hormone receptor variants and response to Pegvisomant in monotherapy or in combination with somatostatin analogs in acromegalic patients: a multicenter study. J Clin Endocrinol Metab 97:E165E172

46. Clemmons DR (2011) Consensus statement on the standardization and evaluation of growth hormone and insulin-like growth factor assays. Clin Chem 57:555-559

47. Milani D, Carmichael JD, Welkowitz J, Ferris S, Reitz RE, Danoff A, Kleinberg DL (2004) Variability and reliability of single serum IGF-I measurements: impact on determining predictability of risk ratios in disease development. J Clin Endocrinol Metab 89:2271-2274

48. Pokrajac A, Wark G, Ellis AR, Wear J, Wieringa GE, Trainer PJ (2007) Variation in GH and IGF-I assays limits the applicability of international consensus criteria to local practice. Clin Endocrinol 67:65-70

49. Colao A, Ferone D, Marzullo P, Lombardi G (2004) Systemic complications of acromegaly: epidemiology, pathogenesis, and management. Endocr Rev 25:102-152

50. Clemmons DR (2004) The relative roles of growth hormone and IGF-1 in controlling insulin sensitivity. J Clin Invest 113:25-27

51. Mazziotti G, Floriani I, Bonadonna S, Torri V, Chanson P, Giustina A (2009) Effects of somatostatin analogs on glucose homeostasis: a metaanalysis of acromegaly studies. J Clin Endocrinol Metab 94:1500-1508

52. Drake WM, Rowles SV, Roberts ME, Fode FK, Besser GM, Monson JP, Trainer PJ (2003) Insulin sensitivity and glucose tolerance improve in patients with acromegaly converted from depot octreotide to Pegvisomant. Eur J Endocrinol 149:521-527

53. Urbani C, Sardella C, Calevro A, Rossi G, Scattina I, Lombardi M, Lupi I, Manetti L, Martino E, Bogazzi F (2013) Effects of medical therapies for acromegaly on glucose metabolism. Eur J Endocrinol 169:99-108

54. Ghigo E, Biller BM, Colao A, Kourides IA, Rajicic N, Hutson RK, De Marinis L, Klibanski A (2009) Comparison of Pegvisomant and long-acting octreotide in patients with acromegaly naïve to radiation and medical therapy. $J$ Endocrinol Invest 32:924-933

55. Lindberg-Larsen R, Møller N, Schmitz O, Nielsen S, Andersen M, Orskov H, Jørgensen JO (2007) The impact of Pegvisomant treatment on substrate metabolism and insulin sensitivity in patients with acromegaly. J Clin Endocrinol Metab 92:1724-1728 
56. Higham CE, Rowles S, Russell-Jones D, Umpleby AM, Trainer PJ (2009) Pegvisomant improves insulin sensitivity and reduces overnight free fatty acid concentrations in patients with acromegaly. J Clin Endocrinol Metab 94:2459-2463

57. Rose DR, Clemmons DR (2002) Growth hormone receptor antagonist improves insulin resistance in acromegaly. Growth Horm IGF Res 12:418-424

58. Trainer PJ, Ezzat S, D'Souza GA, Layton G, Strasburger CJ (2009) A randomized, controlled, multicentre trial comparing Pegvisomant alone with combination therapy of Pegvisomant and long-acting octreotide in patients with acromegaly. Clin Endocrinol 71:549-557

59. Parkinson C, Drake WM, Wieringa G, Yates AP, Besser GM, Trainer PJ (2002) Serum lipoprotein changes following IGF-I normalization using a growth hormone receptor antagonist in acromegaly. Clin Endocrinol 56:303-311

60. Sesmilo G, Fairfield WP, Katznelson L, Pulaski K, Freda PU, Bonert V, Dimaraki E, Stavrou S, Vance ML, Hayden D, Klibanski A (2002) Cardiovascular risk factors in acromegaly before and after normalization of serum IGF-I levels with the GH antagonist Pegvisomant. J Clin Endocrinol Metab 87:1692-1699

61. Berg C, Petersenn S, Lahner H, Herrmann BL, Buchfelder M, Droste M, Stalla GK, Strasburger CJ, Roggenbuck U, Lehmann N, Moebus S, Jöckel KH, Möhlenkamp S, Erbel R, Saller B, Mann K, Investigative Group of the Heinz Nixdorf Recall Study and the German Pegvisomant Observational Study Board and Investigators (2010) Cardiovascular risk factors in patients with uncontrolled and long-term acromegaly: comparison with matched data from the general population and the effect of disease control. J Clin Endocrinol Metab 95:3648-3656

62. Colao A, Pivonello R, Grasso LF, Auriemma RS, Galdiero M, Savastano S, Lombardi G (2011) Determinants of cardiac disease in newly diagnosed patients with acromegaly: results of a 10 year survey study. Eur J Endocrinol 165:713-721

63. Pivonello R, Galderisi M, Auriemma RS, De Martino MC, Galdiero M, Ciccarelli A, D'Errico A, Kourides I, Burman P, Lombardi G, Colao A (2007) Treatment with growth hormone receptor antagonist in acromegaly: effect on cardiac structure and performance. J Clin Endocrinol Metab 92:476-482

64. Auriemma RS, Pivonello R, De Martino MC, Cudemo G, Grasso LF, Galdiero M, Perone Y, Colao A (2012) Treatment with GH receptor antagonist in acromegaly: effect on cardiac arrhythmias. Eur J Endocrinol 168:15-22

65. De Martino MC, Auriemma RS, Brevetti G, Vitale G, Schiano V, Galdiero M, Grasso L, Lombardi G, Colao A, Pivonello R (2010) The treatment with growth hormone receptor antagonist in acromegaly: effect on vascular structure and function in patients resistant to somatostatin analogues. J Endocrinol Invest 33:663-670

66. Giustina A, Mazziotti G, Canalis E (2008) Growth hormone, insulin-like growth factors, and the skeleton. Endocr Rev 29:535-559

67. Mazziotti G, Bianchi A, Bonadonna S, Nuzzo M, Cimino V, Fusco A, De Marinis L, Giustina A (2006) Increased prevalence of radiological spinal deformities in adult patients with $\mathrm{GH}$ deficiency: influence of GH replacement therapy. J Bone Miner Res 21:520-528

68. Bonadonna S, Mazziotti G, Nuzzo M, Bianchi A, Fusco A, De Marinis L, Giustina A (2005) Increased prevalence of radiological spinal deformities in active acromegaly: a cross-sectional study in postmenopausal women. J Bone Miner Res 20:1837-1844

69. Mazziotti G, Gola M, Bianchi A, Porcelli T, Giampietro A, Cimino V, Doga M, Gazzaruso C, De Marinis L, Giustina A
(2011) Influence of diabetes mellitus on vertebral fractures in men with acromegaly. Endocrine 40:102-108

70. Mazziotti G, Bianchi A, Porcelli T, Mormando M, Maffezzoni F, Cristiano A, Giampietro A, De Marinis L, Giustina A (2013) Vertebral fractures in patients with acromegaly: a 3-year prospective study. J Clin Endocrinol Metab 98:3402-3410

71. Fairfield WP, Sesmilo G, Katznelson L, Pulaski K, Freda PU, Stavrou S, Kleinberg D, Klibanski A (2002) Effects of a growth hormone receptor antagonist on bone markers in acromegaly. Clin Endocrinol 57:385-390

72. Parkinson C, Kassem M, Heickendorff L, Flyvbjerg A, Trainer PJ (2003) Pegvisomant-induced serum insulin-like growth factor-I normalization in patients with acromegaly returns elevated markers of bone turnover to normal. J Clin Endocrinol Metab 88:5650-5655

73. Jimenez C, Ayala-Ramirez M, Liu J, Nunez R, Gagel RF (2011) Inhibition of growth hormone receptor activation by Pegvisomant may increase bone density in acromegaly. Horm Metab Res 43:55-61

74. Colao A, Auriemma RS, Lombardi G, Pivonello R (2011) Resistance to somatostatin analogs in acromegaly. Endocr Rev 32:247-271

75. Murray RD, Melmed S (2008) A critical analysis of clinically available somatostatin analog formulations for therapy of acromegaly. J Clin Endocrinol Metab 93:2957-2968

76. Howlett TA, Willis D, Walker G, Wass JAH, Trainer PJ, UK Acromegaly Register Study Group (UKAR-3) (2013) Control of growth hormone and IGF1 in patients with acromegaly in the UK: responses to medical treatment with somatostatin analogues and dopamine agonists. Clin Endocrinol 79:689-699

77. Carmichael JD, Bonert VS, Nuno M, Ly D, Melmed S (2014) Acromegaly clinical trial methodology impact on reported biochemical efficacy rates of somatostatin receptor ligand treatments: a meta-analysis. J Clin Endocrinol Metab 99:1825-1833

78. Amato G, Mazziotti G, Rotondi M, Iorio S, Doga M, Sorvillo F, Manganella G, Di Salle F, Giustina A, Carella C (2002) Longterm effects of lanreotide SR and octreotide LAR on tumour shrinkage and $\mathrm{GH}$ hypersecretion in patients with previously untreated acromegaly. Clin Endocrinol 56:65-71

79. Mazziotti G, Giustina A (2010) Effects of lanreotide SR and Autogel on tumor mass in patients with acromegaly: a systematic review. Pituitary 13:60-67

80. Giustina A, Mazziotti G, Torri V, Spinello M, Floriani I, Melmed S (2012) Meta-analysis on the effects of octreotide on tumor mass in acromegaly. PLoS ONE 7:e36411

81. Salenave S, Boyce AM, Collins MT, Chanson P (2014) Acromegaly and McCune-Albright syndrome. J Clin Endocrinol Metab 99(6):1955-1969

82. Colao A, Attanasio R, Pivonello R, Cappabianca P, Cavallo LM, Lasio G, Lodrini A, Lombardi G, Cozzi R (2006) Partial surgical removal of growth hormone-secreting pituitary tumors enhances the response to somatostatin analogs in acromegaly. J Clin Endocrinol Metab 91:85-92

83. Thorner MO, Strasburger CJ, Wu Z, Straume M, Bidlingmaier M, Pezzoli SS, Zib K, Scarlett JC, Bennett WF (1999) Growth hormone $(\mathrm{GH})$ receptor blockade with a PEG-modified $\mathrm{GH}$ (B2036-PEG) lowers serum insulin-like growth factor-I but does not acutely stimulate serum GH. J Clin Endocrinol Metab 84:2098-2103

84. SOMAVERT EPAR: Available at this URL: http://www.ema. europa.eu/docs/enGB/documentlibrary/EPAR-Summaryforth epublic/human/000409/WC500054622.pdf

85. Jen J, LaBadie RR, Liang Y, Crownover PH, Gao X, HeyHadavi JH (2013) Pegvisomant bioavability of single $30 \mathrm{mg} / \mathrm{ml}$ subcutaneous injection compared to two $15 \mathrm{mg} / \mathrm{ml}$ subcutaneous 
injections: a pharmacokinetic, safety and tolerability study. Growth Horm IGF Res 23:114-119

86. Marazuela M, Ramos-Leví A, Sampedro-Núñez M, Bernabeu I (2014) Cabergoline treatment in acromegaly: pros. Endocrine 46:215-219

87. Kasuki L, Vieira Neto L, Gadelha MR (2014) Cabergoline treatment in acromegaly: cons. Endocrine 46:220-225

88. Higham CE, Atkinson AB, Aylwin S, Bidlingmaier M, Drake WM, Lewis A, Martin NM, Moyes V, Newell-Price J, Trainer PJ (2012) Effective combination treatment with cabergoline and low-dose Pegvisomant in active acromegaly: a prospective clinical trial. J Clin Endocrinol Metab 97:1187-1193

89. Bernabeu I, Alvarez-Escolá C, Paniagua AE, Lucas T, Pavón I, Cabezas-Agrícola JM, Casanueva FF, Marazuela M (2013) Pegvisomant and cabergoline combination therapy in acromegaly. Pituitary 16:101-108

90. Feenstra J, de Herder WW, ten Have SM, van den Beld AW, Feelders RA, Janssen JA, van der Lely AJ (2005) Combined therapy with somatostatin analogues and weekly Pegvisomant in active acromegaly. Lancet 365:1644-1646

91. Neggers SJ, van Aken MO, Janssen JA, Feelders RA, de Herder WW, van der Lely AJ (2007) Long-term efficacy and safety of combined treatment of somatostatin analogs and Pegvisomant in acromegaly. J Clin Endocrinol Metab 92:4598-4601

92. van der Lely AJ, Bernabeu I, Cap J, Caron P, Colao A, Marek J, Neggers S, Birman P (2011) Coadministration of lanreotide Autogel and Pegvisomant normalizes IGF1 levels and is well tolerated in patients with acromegaly partially controlled by somatostatin analogs alone. Eur J Endocrinol 164:325-333

93. Jørgensen JO, Feldt-Rasmussen U, Frystyk J, Chen JW, Kristensen LØ, Hagen C, Ørskov H (2005) Cotreatment of acromegaly with a somatostatin analog and a growth hormone receptor antagonist. J Clin Endocrinol Metab 90:5627-5631

94. Leung KC, Doyle N, Ballesteros M, Waters MJ, Ho KK (2000) Insulin regulation of human hepatic growth hormone receptors: divergent effects on biosynthesis and surface translocation. J Clin Endocrinol Metab 85:4712-4720

95. Bianchi A, Valentini F, Iuorio R, Poggi M, Baldelli R, Passeri M, Giampietro A, Tartaglione L, Chiloiro S, Appetecchia M, Gargiulo P, Fabbri A, Toscano V, Pontecorvi A, De Marinis L (2013) Long-term treatment of somatostatin analog-refractory growth hormone-secreting pituitary tumors with Pegvisomant alone or combined with long-acting somatostatin analogs: a retrospective analysis of clinical practice and outcomes. J Exp Clin Cancer Res 32:40

96. De Marinis L, Bianchi A, Fusco A, Cimino V, Mormando M, Tilaro L, Mazziotti G, Pontecorvi A, Giustina A (2007) Longterm effects of the combination of Pegvisomant with somatostatin analogs (SSA) on glucose homeostasis in non-diabetic patients with active acromegaly partially resistant to SSA. Pituitary 10:227-232

97. Bonert VS, Kennedy L, Petersenn S, Barkan A, Carmichael J, Melmed S (2008) Lipodystrophy in patients with acromegaly receiving Pegvisomant. J Clin Endocrinol Metab 93:3515-3518

98. Maffei P, Martini C, Pagano C, Sicolo N, Corbetti F (2006) Lipohypertrophy in acromegaly induced by the new growth hormone receptor antagonist Pegvisomant. Ann Intern Med 145:310-312

99. Biering H, Saller B, Bauditz J, Pirlich M, Rudolph B, Johne A, Buchfelder M, Mann K, Droste M, Schreiber I, Lochs H, Strasburger CJ (2006) Elevated transaminases during medical treatment of acromegaly: a review of the German Pegvisomant surveillance experience and a report of a patient with histologically proven chronic mild active hepatitis. Eur J Endocrinol 154:213-220
100. Neggers SJ, de Herder WW, Janssen JA, Feelders RA, van der Lely AJ (2009) Combined treatment for acromegaly with longacting somatostatin analogs and Pegvisomant: long-term safety for up to 4.5 years (median 2.2 years) of follow-up in 86 patients. Eur J Endocrinol 160:529-533

101. Feenstra J, Van Aken MO, de Herder WW, Feelders RA, Van der Lely AJ (2006) Drug-induced hepatitis in an acromegalic patient during combined treatment with Pegvisomant and octreotide long-acting repeatable attributed to the use of Pegvisomant. Eur J Endocrinol 154:805-806

102. Trainer PJ, Ezzat S, D'Souza GA, Layton G, Strasburger CJ (2009) A randomized, controlled, multicentre trial comparing Pegvisomant alone with combination therapy of Pegvisomant and long-acting octreotide in patients with acromegaly. Clin Endocrinol 71:549-557

103. Madsen M, Poulsen PL, Ørskov H, Møller N, Jørgensen JOL (2011) Cotreatment with Pegvisomant and a Somatostatin Analog (SA) in SA-Responsive Acromegalic Patients. J Clin Endocrinol Metab 96:2405-2413

104. Bernabeu I, Marazuela M, Lucas T, Loidi L, Alvarez-Escolá C, Luque-Ramírez M, Fernandez-Rodriguez E, Paniagua AE, Quinteiro C, Casanueva FF (2010) Pegvisomantinduced liver injury is related to the UGT1A $1 * 28$ polymorphism of Gilbert's syndrome. J Clin Endocrinol Metab 95:2147-2154

105. Jimenez C, Burman P, Abs R, Clemmons DR, Drake WM, Hutson KR, Messig M, Thorner MO, Trainer PJ, Gagel RF (2008) Follow-up of pituitary tumor volume in patients with acromegaly treated with Pegvisomant in clinical trials. Eur J Endocrinol 159:517-523

106. Buchfelder M, Weigel D, Droste M, Mann K, Saller B, Brubach K, Stalla GK, Bidlingmaier M, Strasburger CJ (2009) Pituitary tumor size in acromegaly during Pegvisomant treatment: experience from MR re-evaluations of the German Pegvisomant Observational Study. Eur J Endocrinol 161:27-35

107. Buhk JH, Jung S, Psychogios MN, Goricke S, Hartz S, SchulzHeise S, Klingebiel R, Forsting M, Bruckmann H, Dorfler A, Jordan M, Buchfelder M, Knauth M (2010) Tumor volume of growth hormone secreting pituitary adenomas during treatment with Pegvisomant: a prospective multicenter study. J Clin Endocrinol Metab 95:552-558

108. Jehle S, Reyes CM, Sundeen RE, Freda PU (2005) Alternate-day administration of Pegvisomant maintains normal serum insulinlike growth factor-i levels in patients with acromegaly. J Clin Endocrinol Metab 90:1588-1593

109. Brian SR, Bidlingmaier M, Wajnrajch MP, Weinzimer SA, Inzucchi SE (2007) Treatment of acromegaly with Pegvisomant during pregnancy: maternal and fetal effects. J Clin Endocrinol Metab 92:3374-3377

110. Didoni G, Grottoli S, Gasco V, Battistini M, Ferone D, Giusti M, Ragazzoni F, Ruffo P, Ghigo E, Minuto F (2004) Cost-of-illness study in acromegalic patients in Italy. J Endocrinol Invest 27:1034-1039

111. Ben-Shlomo A, Sheppard MC, Stephens JM, Pulgar S, Melmed S (2011) Clinical, quality of life, and economic value of acromegaly disease control. Pituitary 14:284-294

112. Moore DJ, Adi Y, Connock MJ, Bayliss S (2009) Clinical effectiveness and cost-effectiveness of Pegvisomant for the treatment of acromegaly: a systematic review and economic evaluation. BMC Endocrinol Disorder 9:20

113. De Marinis L, Bonadonna S, Bianchi A, Maira G, Giustina A (2005) Primary empty sella. J Clin Endocrinol Metab 90:5471-5477

114. Sandret L, Maison P, Chanson P (2011) Place of cabergoline in acromegaly: a meta-analysis. J Clin Endocrinol Metab 96:1325-1335 
115. Giustina A, Karamouzis I, Patelli I, Mazziotti G (2013) Octreotide for acromegaly treatment: a reappraisal. Expert Opin Pharmacother 14:2433-2447
116. Maison P, Tropeano AI, Macquin-Mavier I, Giustina A, Chanson P (2007) Impact of somatostatin analogs on the heart in acromegaly: a metaanalysis. J Clin Endocrinol Metab 92:1743-1747 